\title{
Influence the Performance of Account Representative (X) to the National Taxpayer Compliance (Y1) and the Achievement of Revenue Income Tax under Article 25/29 Agency (Y2) in KPP Primary in Surabaya
}

\author{
Fesi Dita Anugra*, Drs. Djoko Dewantoro, M.Si., Ak., BKP \\ *Corresponding Author: Fesi Dita Anugra
}

\begin{abstract}
Modernizing the tax administration system to give major changes in taxation in Indonesia. Real change is a new position in the civil service, namely the Directorate General of Tax Account Representative. Account Representative took over as Liaison officer (intermediary) between the Tax Office by taxpayers, are expected to emerge through the Account Representative image of the Directorate General of Finance is good. Under Decree Ministry of Financial No. 96/KMK.01/2006, the task of Account Representative, among others, tax guidance and counseling, overseeing compliance from taxpayer, the taxpayer profiling, and the intensification of taxation that led to the rise in tax revenue. With the abundance of the duties it is necessary to the good performance of the Account Representative.
\end{abstract}

This study uses the study is a quantitative method with simple linear regression model to measure how much influence the performance of Account Representative $(X)$ to the National Taxpayer compliance (YI) and the achievement of revenue income tax under Article 25/29 Agency (Y2) in KPP Primary in Surabaya.

Based on the details of the tasks contained in the acquired KMK No. 96/KMK.01/2006 core problem is obtained Account Representative for tasks that every task performed by the Account Representative will be associated with increased taxpayer compliance and increase tax revenues.

The results of this study prove that there is a significant influence in the direction of a positive relationship between the performance of Account Representative (X) to the National Taxpayer formal compliance (Y1) and the achievement of revenue income tax under Article 25/29 Agency (Y2) in KPP Primary in Surabaya. Regression results indicate the $Y 1$ variable $X$ to a constant value of 0.291, 0.126 and regression coefficient of determination coefficient of 0.127, which means $12.7 \%$ of formal adherence to the KPP Taxpayer Primary Agency in Surabaya can be explained by the performance indicators Account Representative. Further results of the regression variable $X$ to $Y 2$ showed a constant value of 0.136, 0.831 and regression coefficient of determination coefficient of 0.196, which means $19.6 \%$ of formal adherence to the KPP Taxpayer Primary Agency in Surabaya can be explained by the performance indicators Account Representative.

Keywords: Taxation, Account Representative, Formal Compliance, Income Tax Section 25/29 Board.

\section{INTRODUCTION}

\subsection{Background}

In 2008 all KPPs have implemented organizational structure based on function and emergence of Account Representative, including all KPP Pratama in Surabaya. In accordance with the duty mandated to Account Representative to oversee the compliance of Taxpayers whose ultimate purpose is to increase tax revenue, it takes a maximum performance for each task Account Representative fulfilled. Performance is the level of achievement of the results of the implementation of certain tasks (Simanjuntak, 2011: 1), so that in accordance with the definition can be concluded that when the performance of a Account Representative well then means every task and obligations are carried out properly implemented. Assessment of good or bad Account Representative performance comes from a process of evaluation or performance appraisal. Performance evaluation is a measuring / evaluating activity to determine the performance of a successful employee or fail to perform its work using its benchmark employment standard (Darmawan, 2009: 65) so that it can be objectively known the performance of Account Representative based on a performance benchmark. 
In relation to the task of Account Representative overseeing the compliance of Taxpayers it is necessary to know that Taxpayer compliance consists of two types, namely Formal Compliance and Compliance of Materials. Formal Compliance generally relates to how Taxpayers' attitude is in compliance with administrative tax laws, whereas Material compliance is related to how the Taxpayer attitude substantively complies with the taxation requirements.

The next task that is mandated to Account Representative is the increase of tax revenue (tax intensification) and realize the target of tax revenue. The statement is in accordance with the obtained through KPP Madya Palembang (www.kppmadyapalembang.pajak.go.id accessed on October 24, 2011 13:18 pm hrs), that is to secure the acceptance of each Account Representative will be given the task to realize acceptance in accordance with its working area and will be directly monitored by Section Head and Head of Office. An increasingly big role will certainly require a better performance of each Account Representative.

\subsection{Formulation of the problem}

In accordance with the description on the background, researchers want to know the answer to the problem with the formulation of the problem as follows:

- What is the effect of Account Representative performance on formal compliance of the Taxpayer Agency at the Primary Tax Office in Surabaya?

- How does Account Representative's performance affect the achievement of Income Tax Article 25/29 Agency at Primary Tax Office in Surabaya?

\section{LITERATURE REVIEW}

\subsection{Performance Theory}

According to Bernardin and Russell (1993: 379) performance is interpreted as "a record of outcomes produced on a specified job function or activity during a specified time period", performance is defined as a record of performance results resulting from the function of a particular job or activity during a certain period of time. Another notion by Simanjuntak (2011: 1) performance is the level of achievement of results on the implementation of certain tasks. The definition of performance is similar to that of Cascio (1995: 275) which is "Performance refer to an employee of assigned task," meaning performance refers to the completion of an employee's assignment to the work he or she has set for it. From this understanding it can be concluded that performance is the result achieved by an employee over a certain period of time and in the field of work he is engaged compared to the level of targets to be achieved and the duty of responsibility.

Performance appraisal by Darmawan (2009: 65) is an attempt to identify and assess the performance aspects that affect the success of non-profit organizations in achieving its objectives, while according to Kae and Leon in Gomes (2003: 135) performance measurement is "a way of measuring the contributions of individuals to their organization, "meaning performance measurement is a way of measuring the contributions of individual members of the organization to its organization. Another understanding according to Simanjuntak (2011: 23) performance evaluation is a system and how the assessment of the achievement of work of a company or organization and achievement of the work of each individual working within and for the company. Meanwhile, according Simanjuntak (2011: 164) one's performance can be measured in two ways. First, compare the results of work against the benchmark results to be achieved. Second, compare the work done on the tasks that should be done.

In order for performance measurement to be objectively measured, certain qualifications are required. There are three important qualifications for the development of objectively measurable performance evaluation criteria (Gomes, 2003: 136-137), namely:

- Relevancy

- Reliability

- Discrimination

The next stage in performing a performance evaluation is to determine who is eligible to perform performance appraisals for employee performance. According Simanjuntak (2011: 120) there are five 
parties that may assess the performance of employees based on consideration of the advantages and disadvantages, namely:

- Employer's immediate supervisor

- Self-Evaluation

- Special Assessment Team

- Related Party

- 360 Degrees Performance Appraisal

In accordance with the explanation of effective performance appraisal above, an objective performance assessment standard with relevant, reliable and discriminant criteria is required. In the Ministry of Finance standardd is reflected in article 11 of Regulation of the Minister of Finance No.190 / PMK.01 / 2008 concerning Guidelines on the Establishment, Evaluation, Assessment, Increase and Decrease of Position and Rank for the Implementing Position Position in the Ministry of Finance and the Head of Regional Office of DGT Jatim I S-107 / WPJ.11 / 2011. Based on the PMK and SK Kakanwil, performance appraisal or evaluation is carried out with benchmarks:

- Implementation of Work.

- Attendance Discipline.

- Attitude and Behavior Against Jobs.

If linked to performance theory, the above three indicators refer to the group's main task information unit and job description of Account Representative, will then be used as an indicator in the questionnaire to measure the performance of an Account Representative through a Likert scale. In social research, Likert Scale is used to measure attitudes, opinions, and persespsi people or a group of people against social phenomena (Sugiyono, 2010: 107).

Furthermore, in the process of appraisal of Account Representative performance required the right performance appraiser. Based on the consideration of the advantages and disadvantages of performance appraisal and supported by article 10 of PMK No.190 / PMK.01 / 2008 stating "direct supervisor conducting evaluator." In this research, Account Representative performance appraisers are direct supervisors, namely Section Head of Supervision and Consultation at the Tax Office where the Account Representative is located.

\subsection{Understanding of Account Representative}

In accordance with the Decree of the Minister of Finance No. 98 / KMK.01 / 2006, for the Tax Office that has implemented the Modern Organization, there has been established Account Representative which assumes tax intensification task through guidance, consultation, analysis and supervision of Taxpayers. According to Article 2, the Decree of the Minister of Finance shall be declared the duty of an Account Representative, namely:

- To supervise taxpayers' tax compliance.

- Guidance / appeal and consultation of taxation techniques to the Taxpayer.

- Preparation of Taxpayer profile.

- Taxpayer performance analysis, Taxpayer data reconciliation in the framework of intensification; and

- Evaluate the results of the appeal under applicable terms.

In addition to the Account Representative duty description according to the Directorate General of Taxes (http://www.kanwilpajakwpbesar.go.id, accessed on October 23, 2011 at 20:37 WIB) there is also the responsibility of an Account Representative, namely:

- Handling a small number of certain Taxpayers.

- Responsible for informing all regulatory changes. 
- Respond to questions or other requests relating to the implementation of obligations or taxation rights.

Implementation of the duties and responsibilities will be the basis for assessment of the implementation of Account Representative tasks.

\subsection{Corporate Taxpayer Compliance}

In relation to taxpayer compliance, Nurmantu (2005: 148) mentions there are two kinds of compliance namely formal compliance and material compliance. The classification of compliance is reinforced by the OECD (2001: 3) which states "In considering definitions of compliance, it is convenient to divide compliance into two key categories, administrative and technical ...". As an explanation for the two categories of taxpayer compliance, Nurmantu (2005: 148) explains that formal compliance is a situation in which the Taxpayer meets the tax obligations formally in accordance with the provisions of the tax law. Along with Nurmantu, the OECD (2001: 3) states that formal compliance is "complying with the administrative rules of lodging and paying on time, what some would include in their definitions of compliance with reporting requirements, procedural compliance or regulatory compliance," meaning administrative compliance (formal) constitutes an adherence to existing taxation regulations and timeliness in paying taxes, compliance with which it includes reporting compliance, compliance with reporting procedures or compliance with regulations. So formal compliance is administrative obedience in the implementation of taxation provisions which include compliance reporting, compliance reporting procedures and compliance with regulations.

The second category of compliance is material compliance. Nurmantu (2005: 148) states, material compliance is a situation where the Taxpayer substantive or essentially meet all the provisions of taxation materials. The statement is in line with OECD (2001), which states material / technical compliance can be obtained when the tax is calculated in accordance with the technical requirements of the tax law or the taxpayer pays the tax obligations in accordance with the provisions of the tax law. It can be concluded when the Taxpayer has formally fulfilled the time of submission of the Annual Income Tax Return then the material compliance is when the SPT Tahuan PPh has been filled with honest, good and technically correct calculation in accordance with applicable taxation provisions.

\subsection{Achievement of Income Tax Article 25/29 Entity}

Achievement of tax revenue is the result of the performance achieved compared with the target of tax revenue that has been set. In this research, the target and the result of the intended tax revenue performance are the target and the revenue result on the Income Tax of Article 25/29 of the Agency at KPP Pratama in Surabaya. Income Tax Article 25/29 of the entity is a tax on income which is regulated in accordance with articles 25 and 29 of Law 36/2008 regarding the installment of income taxes during the tax period for all taxes in one tax year and accrued taxes due in tax installments. If both taxes are added then it will be able to know how much tax received by the Tax Office which derives from the income of the Taxpayer of the Agency during the particular Tax Year. Furthermore, in this study according to the responsibilities of Account Representative will be examined how far the effect of its performance on the achievement of income tax Article 25/29 of the Agency.

\subsection{Hipotesis}

Based on this understanding, in this study the hypothesis is:

- Performance Account Representative against formal compliance of Taxpayer Agency.

$\mathrm{H}_{01}$ : Performance Account Representative does not significantly influence the formal compliance of the Taxpayer Agency.

$\mathrm{H}_{\mathrm{a} 1}$ : Performance Account Representative significantly influence the formal compliance of the Taxpayer Agency.

- Performance Account Representative to the achievement of income tax article 25/29 Article.

$\mathrm{H}_{02}$ : Performance Account Representative has no significant effect on the achievement of Income Tax Article 25/29 Article.

$\mathrm{H}_{\mathrm{a} 2}$ : Account Representative performance significantly influences the achievement of Income Tax Article 25/29. 


\section{RESEARCH METHODS}

\subsection{Research Approach}

The approach used in this study is quantitative, the data collected and then analyzed, the analysis model used is simple linear regression (Sugiyono, 2010: 270).

\subsection{Identify Variables}

Variables used in this study as follows:

- As independent variables are Performance Account Representative (X) and,

- As the dependent variable that is:

$>$ The formal compliance of the Taxpayer Agency $\left(\mathrm{Y}_{1}\right)$

$>$ Achievement of Income Tax Article 25/29 Entity $\left(\mathrm{Y}_{2}\right)$

\subsection{Operational Definition of Variables}

\subsubsection{Account Representative Performance Variables $(X)$}

Is an independent variable (X) where Account Representative performance is the ability as an individual Account Representative in fulfilling the elements evaluated related tasks and responsibilities. In accordance with the Regulation of the Minister of Finance No.190 / PMK.01 / 2008, Decree of the Minister of Finance No. 98 / KMK.01 / 2006 and Decree of the Head of Regional Office of East Java DGT I S-107 / WPJ.11 / 2011 on the theoretical basis, Account Representative in this research is measured through:

\section{a. Work Implementation}

Measured by indicator according to duty of work mandated Minister of Finance Decree Number 98 / KMK.01 / 2006 and Decree of Head of Regional Office of East Java DJP I S-107 / WPJ.11 / 2011 are:

- Monitoring taxpayer compliance compliance.

- Conducting guidance or appeal and consulting taxation techniques to taxpayers.

- Conducting Taxpayer profile.

- Perform Analysis of Taxpayer performance, Taxpayer data reconciliation in the framework of intensification.

- Evaluate the results of the appeal under applicable terms.

- The amount of Rupiah or income taxes received through the issuance of Letter of Appeal and / or proposed Tax Return Letter by Account Representative.

b. Attendance Discipline

Indicators of discipline of work in accordance with Regulation of the Minister of Finance Number 190 / PMK.01 / 2008, namely:

- Absence rate.

- The attendance rate is not timely or returns prematurely and is too late.

- Compliance during business hours.

c. Attitudes and Behavior Against Jobs

With indicators of work discipline in accordance with Regulation of the Minister of Finance Number 190 / PMK.01 / 2008, namely:

- Responsibility for work.

- Cooperation in performing the task.

- Have initiative / initiative in work.

- Integrity in work 


\subsection{Variable Compliance Formal Taxpayer Agency (Y1)}

Dependent variable, formal compliance of the corporate taxpayer, measured by Siti Kurnia Rahayu (2010: 138) and Siti Kurnia Rahayu and Ely Suhayati (2009: 46), OECD (2001), and explanation of the Notice Letter, the compliance of the Taxpayer of the Agency can formally measured through indicators:

- Number of Delivery of Annual Income Tax Return on time.

- Number of Delivery of the Annual Income Tax Return of the Agency overdue or over time within the stipulated period with permission to extend the submission of the Annual Income Tax Return.

- Amount of Delivery of Annual Income Tax Return of the Correction Agency in a timely manner.

All three indicators are then added together, then divided by the number of corporate taxpayers, the result is the ratio of formal Compliance of the Taxpayer Agency for each KPP Pratama in Surabaya. The data is obtained from the Data and Information Processing Division through the Modified Tax Information System (SIPMOD). SIPMOD is a form of implementation of the Information System of the Directorate General of Taxes, which is applied locally (local area network) on each Tax Office containing tax information, Taxpayer database, Target of Receipts, Acceptance Achievement for each type of tax, other related to the data of KPP Pratama. SIPMOD is accessible to all KPP employees in their offices.

\subsection{Variable Achievement Tax Receipts (Y2)}

Achievement of Income in this research is Income Tax article 25/29 Body during Tax Year 2010 with formula as follows:

Total Income Tax Article 25/29 Agency $=(\mathrm{PPh}$ Pasal $25 \times 12)+$ Income Tax Article 29.

Then to measure the achievement of Income Tax Article 25/29 is the Total Income Tax Article 25/29 Agency divided Target Acceptance of Income Tax Article 25/29 Agency. Target revenue and revenue realization data are obtained through the same tax information system with the system used to obtain formal compliance data ie SIPMOD.

\subsection{Population}

The population in this study is all Account Representative KPP Pratama in Surabaya amounted to 263

\subsection{Sample}

Sampling of Account Representative is done by providing sampling criteria examined in this study over the entire population. The criteria is Account Representative work from the beginning to the end of the 2010 Tax Year in the KPP Pratama in the city of Surabaya.

Furthermore, the respondents in this study to answer the questionnaire on the performance of all Account Representatives who worked on the Year 2010 tax is the direct supervisor of the head of the Supervision and Consultation section, so that a Kasi.Waskon can assess the performance of multiple Account Representative at the same time become his subordinates. The selection of respondents is based on PMK No.190 / PMK.01.2008 stating that the right to assess the performance of employees within the Ministry of Finance is the direct superior. In addition, the selection of respondents on the sample is also in accordance with the explanation of Allen Rubin and Earl Barbbie (2008: 342) on purposive sampling, ie "You can use your knowledge of community to hand pick key people who, in your judgment, best represent the range of person who would best know ... and then survey them as to their estimates of those needs ... ", which means when researchers want to examine an object that is difficult to resear due to various limitations, researchers can choose the right people to answer the needs of researchers and can assess the object of research appropriately.

\section{ANALYSIS TECHNIQUE}

\subsection{Method of Succesive Interval (MSI)}

This method is used because the data of independent variable (X) (Account Representative performance) obtained through questionnaire collection still in the form of data with ordinal scale, 
quantitative data processing at least in the form of interval data then before being processed and connected with dependent variable data $(\mathrm{Y} 11, \mathrm{Y} 2 \neg$ (Level of formal compliance of the corporate taxpayer and the achievement of income tax articles 25/29) whose data are scaled ratio, ordinal data is first converted into interval data by using Method of Successive Interval (MSI) in Waryanto (2006: 884), and Isabel (2010: 57).

\subsection{Simple Linear Regression Analysis}

Simple linear regression analysis is a functional or causal relationship analysis of one independent variable with one dependent variable (Sugiyono, 2010: 237). The impact of regression analysis can be used to decide whether the rise and decrease in the value of the dependent variable (the taxpayer's formal compliance rate and the achievement of the Income Tax of Article 25/29) can be done through raising or lowering the value of the independent variable (Account Representative performance), or to improve the state of the dependent variable (WP compliance rate and achievement of corporate income tax) can be done by increasing the value of the independent variable (Account Representative performance) / and vice versa. With the equation as follows:

$$
\mathbf{Y}=\mathbf{a}+\mathbf{b X}+\mathbf{e}
$$

Information:

$\mathrm{Y}=$ The subject / value in the predicted dependent variable

$\mathrm{a}=$ Value $\mathrm{Y}$ if $\mathrm{X}=0$

$\mathrm{b}=$ Figures direction or regression coefficient, which shows the number increase or decrease in dependent variable based on independent variable.

If $b(+)$ then rises, and if $b(-)$ then there is a decrease.

$\mathrm{X}=$ subjects on independent variables that have a certain value.e $=$ nilai residual atau error

Where values $\mathrm{a}$ and $\mathrm{b}$ are searched first using the equation as follows:

$$
\begin{aligned}
\mathbf{a} & =\frac{\left(\sum \mathbf{Y}_{\mathbf{i}}\right)\left(\sum \mathbf{X}_{\mathbf{i}}^{2}\right)-\left(\sum \mathbf{X}_{\mathbf{i}}\right)\left(\sum \mathbf{X}_{\mathbf{i}} \mathbf{Y}_{\mathbf{i}}\right)}{\mathbf{n} \sum \mathbf{X}_{\mathbf{i}}^{2}-\left(\sum \mathbf{X}_{\mathbf{i}}\right)^{2}} \ldots \\
\mathbf{b} & =\frac{\mathbf{n} \sum \mathbf{X}_{\mathbf{i}} \mathbf{Y}_{\mathbf{i}}-\left(\sum \mathbf{X}_{\mathbf{i}}\right)\left(\sum \mathbf{Y}_{\mathbf{i}}\right)}{\mathbf{n} \sum \mathbf{X}_{\mathbf{i}}^{2}-\left(\sum \mathbf{X}_{\mathbf{i}}\right)^{2}} \ldots \ldots \ldots \ldots \ldots \ldots \ldots
\end{aligned}
$$

\section{RESULT}

Based on the results of the calculation is known that partially independent variable is Account Representative (X) performance significantly influence the direction of positive relationship to the dependent variable that is the compliance of Taxpayer Agency (Y1) and the achievement of Income Tax Article 25/29 Agency (Y2) on KPP Pratama in Surabaya for the 2010 Tax Year. The results of this study support previous research conducted by Isabel Maria BF Ximenes (2010) and Iwan Ramdhany (2010) research that stated that Account Representative performance affects the compliance of Corporate Taxpayer and the achievement of tax revenue including Income Tax Article 25/29 Agency.

The result of the calculation states that there is a positive and significant influence between Account Representative (X) performance against formal taxpayer compliance of Agency (Y1). This is because an Account Representative has worked in accordance with the duty mandated to him through the Decree of the Minister of Finance No. 98 / KMK.01 / 2006 on Account Representative at Tax Office that has Implemented Modern Organization, Article 2 states that the task of Account Representative is to oversee compliance Mandatory Tax. Through good performance means Account Representative has done its job well that is supervision of Taxpayer compliance.

Good tax compliance supervision will prevent the occurrence of non-compliance of Taxpayers and disclose non taxpayer compliance which means improving taxpayer compliance. The intended compliance is the formal compliance of Taxpayers in compliance with taxation matters. Compliance can be formally measured through taxpayer compliance in submitting the Annual Tax Return in accordance with the time and other rules that have been set. Through the taxation system in Indonesia 
that is Self Assessment, which means the action of the Taxpayer to be obedient or all matters related to the compliance of taxation obligations entrusted entirely to the Taxpayer, it is expected to appear voluntary compliance of the Taxpayer, but raises the taxpayer voluntary compliance will be very difficult if without a tax officer who oversees the process of fulfilling his tax obligations, the benefits of the taxpayer's apparent behavior, the enforcement of tax regulations, and good taxation services even if the decision is subservient or not ultimately determined by the Taxpayer. This is reflected in the results of this study is that only $12.7 \%$ Account Representative performance is able to explain the compliance of the formal Taxpayer of the Agency while the other $87.3 \%$ will be derived from other factors outside of this research such as taxpayer awareness, tax office services, law enforcement taxation and other factors. This result is in accordance with the statement of Head of Supervision and Consultation of KPP Pratama Surabaya Gubeng, namely that when Account Representative works as maximum as possible then it will not change Taxpayer in fulfilling tax compliance significantly, because the decision to comply or not comes from the Taxpayer's own decision.

The next result is the calculation of regression to find out how much influence the performance of Account Representative to the compliance of Taxpayer Agency at KPP Pratama in Surabaya. Based on calculations obtained by the value of constant $(\alpha)$ of 0.291 which means if the performance Account Representative zero or without any performance, predicted taxpayer compliance Agency at the Tax Office in Surabaya Pratama of $29.1 \%$. The next result is the value of regression coefficient of Account Representative performance variable is equal to 0.126 means that if overall Account Representative performance goes up one unit, then the taxpayer compliance of the Agency at Pratama Tax Service Office in Surabaya is predicted to increase by 0.126 or $12.6 \%$. These results illustrate the magnitude of the effect of AR performance on the KPP Pratama in Surabaya to the formal compliance of the Taxpayer Agency so that through the regression prediction results are expected to increase the performance of AR to improve tax compliance and is an input in improving tax compliance one of the efforts that can be done is to improve the performance of AR in each KPP Pratama.

The result of the next calculation states that there is a positive and significant influence between Account Representative (X) performance against the achievement of Income Tax Article 25/29 Agency (Y2). Thus means Account Representative has performed the function of taxation intensification and other functions that have been established Decree of the Minister of Finance No. 96 / KMK.01 / 2006 well.

Achievement of tax revenue is one indicator of success Tax Office. Various efforts made to achieve the target with as much as possible, among others, through the presence of Account Representative. In accordance with the results of research obtained R2 value of $19.6 \%$ which means the presence of Account Representative able to explain the achievement of Income Tax Article 25/29 Agency, while $80.4 \%$ other influenced by other factors not examined such as the performance of tax collection, tax service performance, Taxpayer awareness and more. The results also show acceptance at KPP Pratama Surabaya adrift far between the highest achievement with the lowest achievement. The researcher confirmed to KPP Pratama Simokerto who get the income tax of Article 25/29 The lowest body is $24,43 \%$, this confirmation is done to Head of Data and Information Processing Section, Kasi PDI (2012) revealed that not optimal this achievement because of the potential of tax is in the Taxpayer Agency in the area of KPP Pratama Surabaya Simokerto very low, but for the target revenue already set over the KPP is too high so that the tax achievement can not be maximized.

Based on the result of regression calculation from Account Representative performance toward the achievement of Income Tax of Article 25/29 of Badan at KPP Pratama in Surabaya resulted calculation of constant value $(\alpha)$ equal to 0,136 meaning if performance Representative Account zero or without performance, predicted attainment of Income Tax Article 25 / 29 Agency by $13.6 \%$. The next result is the value of regression coefficient of performance variable Account Representative is equal to 0,831 meaning if overall Account Representative performance goes up one unit, hence achievement of Income Tax Article 25/29 Agency at Primary Tax Office in Surabaya will experience increase equal to $83,1 \%$. Based on the regression coefficient of $83.1 \%$ can be a reference for KPP Pratama in Surabaya in increasing the achievement of Income Tax Article 25/29 One of them is to improve the performance of AR. 
Influence the Performance of Account Representative (X) to the National Taxpayer Compliance (Y1) and the Achievement of Revenue Income Tax under Article 25/29 Agency (Y2) in KPP Primary in Surabaya

\section{CONCLUSION}

- Based on the average results from the categorization of 17 performance indicators Account Representative note that the average value of AR performance of 4.25 and means can be concluded Account Representative performance at KPP Pratama in Surabaya Year 2010 tax very well. Excellent Account Representative Performance reflected in the job performance, attendance discipline, attitudes and behavior towards the job has been very good as well as supervision of the compliance of the Taxpayer Agency and the achievement of income tax target Article 25/29 Agency.

- Based on the formal compliance data of the Taxpayer Agency and through the descriptive statistical analysis it is known that the average level of formal taxpayer compliance in Surabaya amounted to 37.99\%, and it was concluded that the formal compliance rate of the Taxpayer of the Agency in fulfilling its formal tax obligations on the KPP Pratama in Surabaya is still low. Of the total 52,848 existing corporate taxpayers only 17,237 reporting the Annual Income Tax Return on a timely basis, 1,728 are reporting the Annual Income Tax Returns with an extension license and 547 corporate taxpayers reporting the correction of the Annual Income Tax Return. In total based on the indicators in this study only $36.92 \%$ of the formal taxpayer of the Board in the Tax Year 2010. The highest compliance is in the KPP Pratama Surabaya Pabean Cantikan that is equal to $44.66 \%$ and compliance of Taxpayers The lowest formally formal bodies are in the KPP Pratama Surabaya Wonocolo.

- According to the data of income tax revenue achievement Article 25/29 Agency Year 2010 tax and descriptive statistical analysis known the average achievement of Income Tax Article 25/29 Agency at KPP Pratama in Surabaya amounted to $75.20 \%$ which means it can be concluded that KPP Pratama in Surabaya has well realized the revenue target of Income Tax Article 25/29 Agency. The highest achievement is achieved by KPP Pratama Karang Pilang that is equal to $107.34 \%$ and the lowest achievement in KPP Pratama Surabaya Simokerto.

- Based on the results of calculations and regression analysis concluded that there is a significant influence partially between Account Representative performance of formal compliance of Taxpayer Agency at KPP Pratama in Surabaya formally with a confidence level of 95\%. The next result states that the direction of influence over the relationship is positive, with the value of regression coefficient of +0.126 which means if the performance of Account Representative increased will be accompanied by the increase in compliance of the Taxpayer of the Agency formally at KPP Pratama in Surabaya.

- Based on the calculation and regression analysis, it is concluded that there is a significant influence either partially between Account Representative performance towards the achievement of Income Tax of Article 25/29 of the Agency at KPP Pratama in Surabaya with the trust level of 95\%. The next result states that the direction of influence on the relationship is positive, with the value of regression coefficient of +0.831 which means the achievement of Account Representative performance increases will be accompanied by an increase in income tax revenue Article 25/29 Agency at KPP Pratama in Surabaya.

\section{REFERENCES}

[1] Bernardin, John H. dan Joyce E. A. Russell 1993. Human Resources Management an Experiental Approach. New York: McGraw-Hill, Inc.

[2] Cascio, Wayne F. 1995. Managing Human Resources: Productivity, Quality of Work Life, Profits. Fourth Edition. Singapore: McGraw-Hill, Inc.

[3] Darmawan, Didit. 2009. Motivasi dan Kinerja. Surabaya: Metromedia Education.

[4] 2009. Perilaku dan Kinerja Karyawan. Surabaya: Metromedia Education.

[5] Departemen Keuangan Republik Indonesia. 2011. "Data Pokok APBN 2005-2010". Departemen Keuangan Republik Indonesia.

[6] Departemen Pendidikan dan Kebudayaan. 1988. Kamus Besar Bahasa IndonesiaJakarta : Balai Pustaka

[7] Ghozali, Imam. 2011. Aplikasi Analisis Multivariate dengan Program IBM SPSS 19. Semarang: Badan Penerbit Universitas Diponegoro.

[8] Gomes, Faustino Cardoso. 2003. Manajemen Sumber Daya Manusia. Yogyakarta: Andi. 
Influence the Performance of Account Representative (X) to the National Taxpayer Compliance (Y1) and the Achievement of Revenue Income Tax under Article 25/29 Agency (Y2) in KPP Primary in Surabaya

[9] Harimawan, Muhamad Iwan. 2008. Pengaruh Kompetensi Individu, Kepemimpinan, dan Reformasi Administrasi Perpajakan Terhadap Kinerja Account Representative pada KPP Madya Surabaya di Jawa Timur. Thesis. Universitas Airlangga

[10] Idris, Amirul. 2010. "Bagan Pajak Penghasilan Badan" dalam Slide Power Point Pajak Penghasilan Badan. Surabaya: Ikatan Akuntan Indonesia.

[11] Nurmantu, Safri. 2005. Pengantar Perpajakan. Edisi Tiga. Jakarta: Granit.

[12] OECD. 2001. Practice Note about Compliance Measurement. OECD Center For Tax Policy and Administration.

[13] Opini. 2005. Kode Etik. Dalam http://www.kppbumn.depkeu.go.id/Tentang Kami/Kode_Etik.htm. yang diakses pada tanggal 10 Januari 2012 Pukul 19.00 WIB.

[14] Opini. 2008. Account Representative. Dalam www.kanwilpajakwpbesar.go.id/?task=static\&PID=31, yang diakses pada tanggal 23 Oktober 2011 Pukul 20.37 WIB.

[15] Opini. 2010. Peran Account Representative Semakin Meningkat. Dalam http://www.kppmadyapalembang. pajak.go.id/content/view/318/1/,yang diakses pada tanggal 24 Oktober 2011 Pukul 13.18 WIB

[16] Rahayu, Siti Kurnia. 2010. Perpajakan Indonesia: Konsep dan Aspek Formal. Yogyakarta: Graha Ilmu.

[17] __ dan Ely Suhayati. 2009. Perpajakan: Teori dan Teknis Perhitungan. Yogyakarta: Graha Ilmu.

[18] Ramdhanny, Iwan. 2010. Pengaruh Kinerja Account Representative Terhadap Efektifitas Pencapaian Penerimaan Pajak Pada Kantor Pelayanan Pajak Pratama di Kota Bandung. Skripsi. Bandung: Universitas Pendidikan Indonesia.

[19] Republik Indonesia. Keputusan Menteri Keuangan Nomor 544/KMK.04/2000 tentang Kriteria Wajib Pajak yang Dapat Diberikan Pengembalian Pendahuluan Kelebihan Pembayaran Pajak.

[20] Republik Indonesia. Keputusan Menteri Keuangan Nomor 534/KMK.04/2000 tentang Bentuk Dan Isi Surat Pemberitahuan Serta Keterangan Dan Atau Dokumen yang Harus Dilampirkan.

[21] Republik Indonesia, Keputusan Menteri Keuangan Nomor 98/KMK.01/2006 tentang Account Representative pada Kantor Pelayanan Pajak yang telah Mengimplementasikan Organisasi modern.

[22] Republik Indonesia. Peraturan Menteri Keuangan Nomor 1/PM.3/2007 tentang Kode Etik Pegawai Direktorat Jenderal Pajak.

[23] Republik Indonesia. Peraturan Menteri Keuangan Nomor 68/PMK.01/2008 tentang perubahan atas KMK nomor 98/KMK.01/2006 tentang Account Representative Pada Kantor Pelayanan Pajak yang Telah Mengimplementasikan Organisasi Modern.

[24] Republik Indonesia. Peraturan Menteri Keuangan Nomor 192/PMK.03/2007 tentang Tata Cara Penetapan Wajib Pajak dengan Kriteria Tertentu dalam Rangka Pengembalian Pendahuluan Kelebihan Pembayaran Pajak.

[25] Republik Indonesia. Peraturan Menteri Keuangan Nomor 190/PMK.01/2008 tentang Pedoman Penetapan, Evaluasi, Penilaian, Kenaikan dan Penurunan Jabatan dan Peringkat Bagi Pemangku Jabatan Pelaksana di Lingkungan Departemen Keuangan.

[26] Republik Indonesia. Surat Edaran Dirjen Pajak SE-06/PJ.9/2001 tentang Pelaksanaan Ekstensifikasi Wajib Pajak dan Intensifikasi Pajak.

[27] Republik Indonesia. Surat Edaran Direktur Jenderal Pajak Nomor: SE-33/PJ./2007 tentang Panduan Pelaksanaan Kode Etik Pegawai Direktorat Jenderal Pajak.

[28] Republik Indonesia. Undang-undang Nomor 6 Tahun 1983 Tentang Ketentuan Umum Dan Tata Cara Perpajakan Sebagaimana Telah Diubah Terakhir Dengan Undang-Undang Nomor 28 Tahun 2007.

[29] Republik Indonesia. Undang-undang Nomor 7 Tahun 1983 Tentang Pajak Penghasilan Sebagaimana Telah Diubah Terakhir Dengan Undang-Undang Nomor 36 Tahun 2008.

[30] Robbins, Stephen P. 2009. Organisational Behaviour: global and sourthern African perspectives. $2^{\text {nd }}$ Edition. South Africa : Pearson.

[31] Rubin, Allen dan Earl Barbie. 2008. Research Method for Social Work. $6^{\text {th }}$ Edition. USA: Thomson Brooks/Cole.

[32] Simanjuntak, Payaman J. 2011. Manajemen dan Evaluasi Kinerja, Edisi Tiga. Jakarta: LP-FEUI.

[33] Solimun. 2002. Multivariate Analysis Structual Equation Modelling Lisrel dan Amos. Malang: Universitas Brawijaya.

[34] Suandy, Erly. 2008. Hukum Pajak. Edisi Empat Jakarta: Salemba Empat.

[35] Sugiyono. 2010. Metode Penelitian Administrasi. Bandung: Alfabeta.

[36] 2010. Metode Penelitian Bisnis. Bandung: Alfabeta. 
Influence the Performance of Account Representative (X) to the National Taxpayer Compliance (Y1) and the Achievement of Revenue Income Tax under Article 25/29 Agency (Y2) in KPP Primary in Surabaya

[37] Suryadi. 2006. "Model Hubungan Kausal Kesadaran, Pelayanan, Kepatuhan Wajib Pajak, dan Pengaruhnya Terhadap Kinerja Penerimaan Pajak: Suatu Survey di Wilayah Jawa Timur" dalam Lingua: Jurnal Keuangan Publik Volume 4 Nomor 1 halaman 105-121, April 2006. Jakarta: Badan Pendidikan dan Pelatihan Keuangan.

[38] Wardani, Eka Suci. 2011. Pengaruh Kualitas Pelayanan dan Efektifitas Pengawasan Account Representative Terhadap Kepatuhan Wajib Pajak Orang Pribadi Pada Kantor Pelayanan Pajak Pratama Sidoarjo Utara. Skripsi. Surabaya: Universitas Airlangga.

[39] Waryanto, Budi and Yuan Astika Milafati. 2006. 'Transformasi Data Skala Ordinal Ke Interval dengan Menggunakan Makro Minitab” dalam Lingua : Jurnal Informatika Pertanian volume 15 halaman 881-896. Jakarta: Litbang Departemen Pertanian.

[40] Widodo, Yudi Tri. 2010. Analisis Pengaruh Sikap Atas Peningkatan Kualitas Pelayanan Perpajakan Terhadap Niat Berperilaku Patuh Wajib Pajak Orang Pribadi di Kantor Pelayanan Pajak Pratama Sidoarjo Utara. Skripsi. Surabaya: Universitas Airlangga.

[41] Wijaya, Indra .dkk. 2012. Istri Dhana Diduga Ikut Terlibat. (online). http://www.tempo.co/read/news/ 2012/02/27/063386534/Istri-Dhana-Diduga-Ikut-Terlibatyang diakses pada Tanggal 2 Maret 2012 Pukul 14.00 WIB.

[42] Ximenes, Isabel Maria B.F. 2010. Pengaruh Kinerja Account Representative Terhadap Kepatuhan Wajib Pajak Badan Pada Kantor Pelayanan Pajak di Kota Bandung. Skripsi. Bandung: Unikom.

[43] www.bi.go.id/web/id/Publikasi/Jurnal+Ekonomi/, yang_diakses pada 7 Oktober 2011 Pukul 13.00 WIB.

[44] www.books.google.com

[45] www.google.co.id

[46] www.pajak.go.id/struktur_organisasi, yang diakses pada tanggal 6 Maret 2012 pukul 15.00 WIB

[47] www.pajak.taxes.blogspot.com, yang diakses pada tanggal 17 Oktober 2011 Pukul 15.00 WIB

\section{AUTHOR'S BIOGRAPHY}

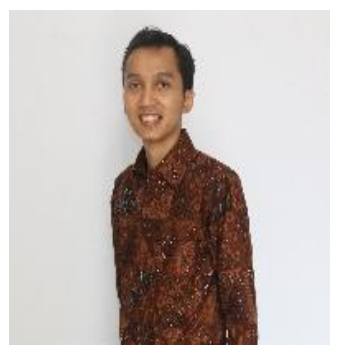

Fesi Dita Anugra, SA.,Ak.CA. is a master of accounting student at Airlangga University. obtained a bachelor's degree in accounting at airlangga university in 2012. interested in research on behavior in organizations and matters that have an impact and influence it.

Citation: Fesi Dita Anugra, et al. “ Influence the Performance of Account Representative (X) to the National Taxpayer Compliance (Y1) and the Achievement of Revenue Income Tax under Article 25/29 Agency (Y2) in KPP Primary in Surabaya" International Journal of Managerial Studies and Research (IJMSR), vol 8, no. 1, 2020, pp. 17-27. doi: http://dx.doi.org/10.20431/23 49-0349.0801001.

Copyright: (C) 2020 Authors. This is an open-access article distributed under the terms of the Creative Commons Attribution License, which permits unrestricted use, distribution, and reproduction in any medium, provided the original author and source are credited. 